\title{
Life Cycle Cost (LCC) Analysis for Rigid Pavement Rehabilitation and Maintenance in Malaysia
}

\author{
Monirul Islam, Sarajul Fikri Mohamed, Syamsul Hendra Mahmud, Alghamdi Khalid Ahmed \\ M, Karban Abdullah Saeed
}

\begin{abstract}
Many scholars claimed that due to maintenance, high reconstruction and construction costs in Malaysia, LCC shows an important role in estimating the cost of rigid pavement. Because of the government's expenditure and high budget allocation on pavement rehabilitation and maintenance work in Malaysia, choosing the most cost-effective pavement maintenance, maximizing the budget allocation and rehabilitation alternatives is essential for transportation agencies. A useful technique LCC of economic analysis that measures the different solutions of cost-effectiveness to rehabilitation and maintenance within the same category of roads. To generate a broad and accurate LCC output, however, it is necessary to ensure that the value information inputs are ready and of sufficient quality to use in the estimation of the LCC. This article shows the findings of Malaysia's systematic literature review inputs for LCC cost information study of dynamic pavement rehabilitation and maintenance. The literature study results showed that the greater part of key players in the construction industry are aware of the need for LCC analysis in the rigid rehabilitation and maintenance of the pavement. In Malaysia the LCC current state system of rigid pavement rehabilitation and maintenance, however, is still in its not only infancy stage but also is not ready for the difficulties to be implemented in achieving quality cost data to generate a reliable and comprehensive analysis of life cycle cost. The present findings of the paper which provide information on cost data current state inputs in the construction industry from the LCC analysis of rigid pavement rehabilitation and maintenance.

Keywords: Cost data input; rigid pavement; rehabilitation; maintenance; life cycle cost (LCC).
\end{abstract}

\section{INTRODUCTION}

In recent years, Malaysia's transport system is experiencing rapid development that can support Malaysia's economic growth and national development [1] . In the Eleventh

Revised Manuscript Received on February 05, 2020.

* Correspondence Author

Monirul Islam*, Department of Quantity Surveying, Faculty of Built Environment, University Teknologi Malaysia, Johor Bahru, Malaysia, monir176@gmail.com.+601114310359

Sarajul Fikri Mohamed, Department of Quantity Surveying, Faculty of Built Environment, University Teknologi Malaysia, Johor Bahru, Malaysia, sarajul@utm.my.

Syamsul Hendra Mahmud, Department of Quantity Surveying, Faculty of Built Environment, University Teknologi Malaysia, Johor Bahru, Malaysia, b-syamsul@utm.my.

Alghamdi Khalid Ahmed M, Umm Alqura University, College of Engineering and Islamic Architecture, oraijart@gmail.com.

Karban Abdullah Saeed, Umm Alqura University, College of Engineering and Islamic Architecture, Arch-ask@hotmail.com.

(C) The Authors. Published by Blue Eyes Intelligence Engineering and Sciences Publication (BEIESP). This is an open access article under the CC BY-NC-ND license (http://creativecommons.org/licenses/by-nc-nd/4.0/)
Malaysia Plan (2016 to 2020), approximately 3,000 kilometers of paved road will be built where, in the 2018 budget of Malaysia, the Prime Minister declared that RM2 billion was allocated to the Pan-Borneo Highway construction and RM934 million to construct and improve infrastructure in Malaysia's rural road areas [2]. Although the government has allocated this sum of budget for the construction of new roads and highways, it is not possible to ignore the reliability of existing roads during their lifetime. More recent attention has focused on maintaining the infrastructure resources in good condition to ensure that the system remains successful and performs in compliance with its necessary requirements throughout its lifetime[1].The Government of Malaysia has allocated a huge budget to improve and maintain the current road condition, where from 2001 to 2010 approximately RM5 billion was spent on the rehabilitation and maintenance of all federal roads in Malaysia[1]. In contrast, PLUS Malaysia Bhd invested around RM1 billion in 2016 to protect the country's 5,000 kilometers of highways [3]. Therefore, due to increasing demand for road funds and budget constraints, transport agencies (i.e. consumers, stakeholders, administrators, concessionaires, etc.) need to determine the best total ownership costs and cost-effective pavement maintenance alternatives. This can be done by taking into account the overall cost estimate for road construction and maintenance during the design phase[4][5]. Many asset owners concentrated only on the lowest initial cost of capital, but disregarded future costs as an important aspect of maximizing overall asset costs and generating the best value for money [1]. Maintenance can affect the quality of the living environment as poor maintenance of existing infrastructure and facilities creates obstacles and hinders users[6].Life cycle costs define as an economic evaluation technique using a mathematical method to estimate the total cost of ownership of an asset over its expected lifetime and determining the cost-effectiveness option among various competing alternatives[7].The government of Malaysia should concentrate on preventive maintenance and a life-cycle costing implementation approach in road maintenance programs [8]. This shows that LCC has increasingly been recognized as an important tool for developing more cost-effective strategies for transport agencies to leverage the budget allocated to road and highway infrastructure maintenance in Malaysia.

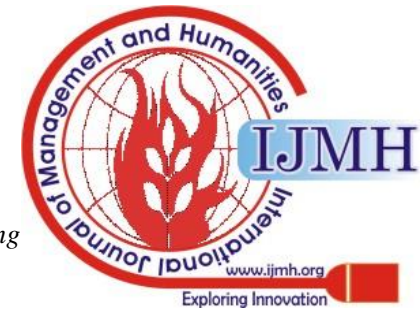


Nevertheless, most studies in the field of LCC analysis concentrated only on the methods and models for LCC calculation, but there is a very limited study that adequately stressed the state and performance of cost information inputs (i.e. availability of accessibility, cost data, reliability and currency). to be used to produce reliable LCC outputs for rigid pavement maintenance and rehabilitation. This study is therefore important to assist transport agencies in carrying out rigid pavement maintenance and rehabilitation LCC through the use of quality inputs cost data.[6], [7], [9].

The objective of the paper presents the findings of a systematic literature review in the Malaysian construction industry on the status of cost information inputs for LCC study of dynamic rigid pavement rehabilitation and maintenance. The results recorded for literature in this paper were part of an ongoing two-year postgraduate study carried out by the first author on the investigation of cost information used as inputs to generate a detailed and accurate LCC estimate of dynamic rigid pavement rehabilitation and maintenance approaches in the Malaysian construction industry.

\section{LITERATURE REVIEW}

\section{A. Overview of Rigid Pavement}

There are two main categories of paved roads in Malaysia, which are flexible and rigid pavements[1]. The rigid pavement is graded on the basis of its concrete surfaces and foundations, which means high strength and enduring characteristics that allow it to cover any minor irregularities in the pavement's sub-grade or sub-base, layers [10]. Figure 1 shows the differences in the flexible and rigid pavement designs between construction layers. Generally, there are four (4) layers of rigid asphalt, i.e. sub-grade, sub-base, base level, concrete slab, and reinforced metal. There are three stiff pavement forms, i.e. JPCP, Joint Reinforced Concrete Pavement (JRCP) and Continuously Reinforced Concrete Pavement (CRCP) [11]. The rigid pavement has a low cost of maintenance but the initial high cost of capital. On the other hand, the flexible pavement has low initial costs but high maintenance costs [5] .Nonetheless, due to lack of knowledge of rigid pavement advantages, the number of new rigid pavement construction in Malaysia is very small, the rigid pavement of which accounts for only less than $1 \%$ of all Malaysian roads[1].

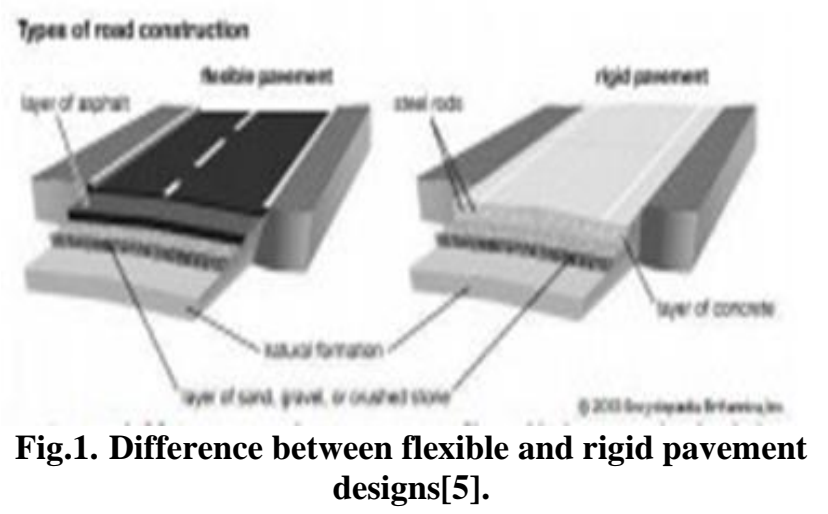

\section{B. Rigid Pavement Maintenance and Rehabilitation}

Traffic there are several factors that can contribute to elastic pavement degradation over time such as traffic volume changes, underground system movement or environmental factors. It is practically possible to classify road maintenance jobs into three main categories: preventive maintenance, corrective maintenance and emergency maintenance. Preventive maintenance usually deals with preventive practices conducted annually to delay or avoid the possibility of pavement distress occurring to ensure its serviceability for example diamond grinding, slab stabilization, dowel bar retrofitting [9],[12]. Corrective maintenance: Refers to the tasks carried out in the pavement after the distress to restore and enhance the pavement's serviceability for example complete repairs, partial repairs, cracking and sealing[9], [12]. Emergency maintenance applied in emergency situations requiring immediate assistance [13]. Figure 2 illustrates the summarized six steps of the general process of selecting the most appropriate and cost-effective rehabilitation and maintenance strategy for existing flexible pavement in relation to that, the authors also have highlighted in their study that the maintenance and rehabilitation strategy selection process might be different in the details depending on the highway agencies; however, the typical process consists of the six main activities which are data collection of the necessary information, to evaluate the current condition of flexible pavement and type of maintenance and rehabilitation method needed. Besides that, the information is needed to predict the performance of each strategy and estimate the cost of each strategy. For example, roadway section definition, traffic analysis, distress survey etc. Pavement evaluation is carried out to assess the present condition of the flexible pavement i.e. type of deterioration, deficiencies to be addressed by rehabilitation, uniform sections for rehabilitation design and construction over project length. Selection of flexible pavement maintenance and rehabilitation techniques that are best suited to the correction of existing distress and achieved the required improvements of the flexible pavement structure. Formation of maintenance and rehabilitation strategies, developed in sufficient detail that the performance and the cost of each strategy can be estimated. Carry out life cycle cost analysis by comparing the monetary costs and benefits of the different rigid pavement maintenance and rehabilitation approach alternatives over an analysis period. Selection of rigid pavement maintenance and rehabilitation approach considering the monetary factors and non-monetary factors together among the alternatives considered. Preventive maintenance techniques should be scheduled to maximize safety, maintainability, and the cost-effectiveness of pavement preservation efforts. Cost-effectiveness can be defined as the relationship between the long-term cost of a pavement maintenance treatment over a given evaluation period and the improvement in serviceability of the pavement.

Several studies have been done, including those to evaluate and define the various methods for determining the cost-effectiveness of maintenance treatments. Methods currently being used and the pertinent information required for the analysis [1].

Retrieval Number: F0605024620/2020@BEIESP

DOI:10.35940/ijmh.F0605.024620

Journal Website: www.ijmh.org

Published By:

Blue Eyes Intelligence Engineering

\& Sciences Publication

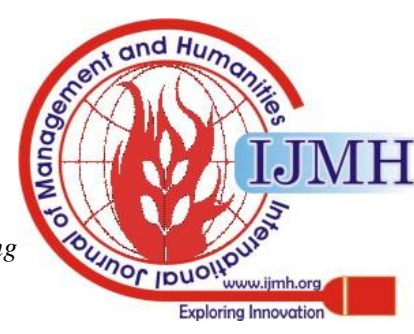


The life-cycle costing approach does not consider the condition of the pavement in the analysis and assumes that the lowest cost treatment is the best one. In the cost-effectiveness analysis scheme, a pavement performance curve is developed using one of a number of approaches. The vertical axis represents some performance index, usually pavement serviceability index (PSI) or pavement condition index, and the horizontal axis represents time. With the PSI approach, not all the deficiencies that require pavement maintenance are captured, because the major performance index is computed from roughness measurements. Additionally, the relationship between the applied treatment and the additional service life as a result of the treatment must be considered. With the equivalent annual cost (EAC) approach, performance is not considered. The same can be said of the longevity cost index method. Each of these methods has strengths and weaknesses, and the user, must consider all the pertinent factors.

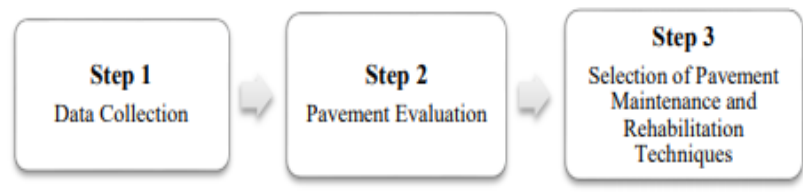

\begin{tabular}{|c|c|c|}
\hline Step 6 & Step 5 \\
$\begin{array}{c}\text { Selection of Pavement } \\
\text { Maintenance and } \\
\text { Rehabilitation Strategy }\end{array}$ & $\begin{array}{c}\text { Life Cycle Cost Analysis } 4 \\
\text { of Pavement Maintenance } \\
\text { and Rehabilitation } \\
\text { Strategies }\end{array}$ & $\begin{array}{c}\text { Formation of Pavement } \\
\text { Maintenance and } \\
\text { Rehabilitation } \\
\text { Strategies }\end{array}$ \\
\hline
\end{tabular}

Fig. 2. Pavement rehabilitation process[1]

\section{Life Cycle Cost (LCC) of maintenance during the in-use phases of rigid pavement}

Road Life Cycle Cost is fast becoming a key instrument in improving cost effectiveness of pavement evaluation, where LCC became popular since the 1960s when the US Government Agencies used life cycle cost to increase the cost-effectiveness of equipment procurement [14]. LCC can be defined as "an economic assessment technique that uses the mathematical method to estimate the total ownership costs of an asset or system over an anticipated lifespan[7], [15], [16]. LCC is recommended to be used as a medium when selecting the most cost-effective road designs or evaluating bids. Previous research has indicated that LCC offers a complete and comprehensive costing model to the infrastructure asset owner as it commonly integrated with the whole cost of ownership [13] . Currently, in the construction industry especially in road construction and maintenance, the practice of LCC is still at its early stages even though it has been extensively applied in the United States and European countries [7]. Table 1 below shows the list of other countries and their state of life cycle cost practice in comparison with Malaysia. It was reported that the public sector clients in several countries like the Netherlands, Finland, UK, Sweden etc., have been used LCC to estimate the long-term cost of the public project [13]. The construction industry in Malaysia is the only industry that practices the LCC analysis as an economic assessment technique [7]

Table 1: The comparison of the state of life cycle cost practice in Malaysia and other countries

\begin{tabular}{|c|c|c|c|c|c|}
\hline Country & $\begin{array}{l}\text { LCC is a } \\
\text { mandatory } \\
\text { requirement }\end{array}$ & $\begin{array}{l}\text { LCC is applied but } \\
\text { not as } \\
\text { a mandatory } \\
\text { requirement }\end{array}$ & $\begin{array}{l}\text { LCC is } \\
\text { used } \\
\text { on a trial } \\
\text { basis }\end{array}$ & $\begin{array}{l}\text { LCC is yet } \\
\text { to } \\
\text { be applied }\end{array}$ & Reference(s) \\
\hline MALAYSIA & $\bullet$ & & & & [1] \\
\hline $\begin{array}{l}\text { The United } \\
\text { Kingdom }\end{array}$ & $\bullet$ & & & & [1] \\
\hline $\begin{array}{l}\text { The United } \\
\text { States }\end{array}$ & - & & & & [1] \\
\hline Canada & $\bullet$ & & & & [1] \\
\hline Japan & & $\bullet$ & & & [1] \\
\hline New Zealand & & $\bullet$ & & & [1] \\
\hline Australia & & $\bullet$ & & & [1] \\
\hline Singapore & & & $\bullet$ & & [1] \\
\hline Indonesia & & & & $\bullet$ & [1] \\
\hline China & & & $\bullet$ & & [1] \\
\hline India & & & $\bullet$ & & {$[1]$} \\
\hline Austria & & $\bullet$ & & & {$[1]$} \\
\hline Vietnam & & & & $\bullet$ & [1] \\
\hline Mauritius & & & & $\bullet$ & {$[1]$} \\
\hline Finland & $\bullet$ & & & & [1] \\
\hline Chile & & & $\bullet$ & & [1] \\
\hline Sweden & $\bullet$ & & & & [1] \\
\hline
\end{tabular}


Life Cycle Cost (LCC) Analysis for Rigid Pavement Rehabilitation and Maintenance in Malaysia

\begin{tabular}{|l|c|c|c|c|c|}
\hline Denmark & $\bullet$ & & & & {$[1]$} \\
\hline Ghana & & & & $\bullet$ & {$[1]$} \\
\hline The Netherlands & & $\bullet$ & & & {$[1]$} \\
\hline Korea & & $\bullet$ & & & {$[1]$} \\
\hline Slovenia & & & & & {$[1]$} \\
\hline Switzerland & $\bullet$ & & & & {$[1]$} \\
\hline Argentina & & $\bullet$ & & & {$[1]$} \\
\hline Germany & & $\bullet$ & & & {$[1]$} \\
\hline France & & & & & {$[1]$} \\
\hline
\end{tabular}

Furthermore, the outcome of the initial study by [7] shows that most of the government agencies are aware that LCC should be practiced and applied in the construction industry including in the rigid pavement maintenance and rehabilitation. In the United States and the European countries, i.e. Sweden and the United Kingdom, they have fully implemented and practiced the LCC analysis. The UK construction industry has published national standard guidelines to be used for LCC analysis practice, i.e. [17] , "International Standard: Buildings and Constructed Assets-Service Life Planning. Part 5: Life Cycle Costing". On the other hand, in Malaysia, the Public Works Department (PWD) has published a standard guideline of LCC called "Garis Panduan Pengiraan Kitaran Hayat (KKH)" (Standard Guideline of Estimating Life Cycle Cost (LCC)).The Malaysia standard guideline of LCC aims to deliver the appropriate methodology of practicing LCC analysis for the upcoming public projects in the Malaysian construction industry. It consists of cost LCC models, breakdown structure (CBS) standards, methodologies and other fundamental components of LCC to be used for public building and civil infrastructure projects in Malaysia. However, the PWD guideline is lacking methodology and information to attain a complete, up-to-date and reliable cost data inputs to produce a comprehensive and reliable LCC output for rigid pavement maintenance and rehabilitation in the Malaysian construction industry [16]. LCC can be applied in the maintenance of the asset or system during the in-use phases, which evaluates the life cycle cost over a period of analysis after the construction phase completed until the end of the life phase of the asset. Based on the condition of the asset over the period of analysis, the owner of the asset can identify whether to maintain or renew the asset [17].LCC is not only being used by the transportation agencies as a decision support tool for selecting pavement type, but it was also used to evaluate the cost comparison between different rehabilitation strategies within a similar road pavement type. LCC was applied as an economic assessment technique for the valuation of estimated deterioration models and the cost of routine and periodic maintenance, repair and rehabilitation of road pavement [18] .LCC plays an important role in pavement maintenance as the future cost of pavement can be a significant contribution to the total cost of the asset. For instance, in Florida, a state highway initial construction costs comprised $47 \%$ of the whole life cycle cost of the highway, nonetheless, the future maintenance and rehabilitation costs encompassed $53 \%$. This example shows that the future maintenance cost is higher than the initial construction cost of a highway, in which the study offers some important insight into the implementation of LCC analysis for road pavement maintenance. The output of reliable LCC analysis is not solely on the selection of an alternative over the other, but it is about the most cost-effective design strategy selected for certain conditions and factors that influence cost-effectiveness.[16]. There are three main phases of the LCC estimation process, which are data inputs, conversion and outputs [7]. The output of the LCC estimation is highly depending on the accuracy of the input variables. Data is one of the most vital assets in a pavement management organization. However, many commentators asserted that the significant setback of LCC practice in the early phase of the project is the difficulty to identify and acquire. quality, reliable and complete data due to lack of primary information, road work cost database and current cost estimation methods for the rigid pavement maintenance and rehabilitation. The LCC analysis requires comprehensive and specific data information that meets the data input quality requirements of LCC analysis, i.e. material unit cost, traffic volumes, materials volumes, etc. [19].Due to the complexity of LCC analysis, the estimators and practitioners tend to miscalculate, make assumptions, estimates and projections from inadequate input data that have a tendency to produce non-reliable and inaccurate LCC outputs[10], [20]. In conducting the LCC of rigid pavement with specific reference to its maintenance and rehabilitation approaches, it is important to recognize the certainty of input data since the data will determine the reliability of the LCC outputs. Unfortunately, the past studies have shown that the difficulties in the implementation of LCC analysis of rigid pavement maintenance are the lack of current and reliable maintenance cost data of rigid pavement in Malaysia [19], [20]. In addition, most of the scholars and estimators are mainly focused on LCC conversion; however, very limited research has been carried out in the past to identify the quality of cost data (i.e. availability, accessibility, currency and reliability of data inputs) as inputs for producing a comprehensive and reliable LCC analysis of rigid pavement maintenance and rehabilitation in the Malaysian construction industry.

\section{Cost Components of LCC for rigid pavement maintenance and rehabilitation}

The maintenance and rehabilitation costs of rigid pavement consist of cost acquired by the transportation agencies during the performance of a maintenance activity at a certain work site, on a specific day and time. The maintenance (repair) and replacement (renewal) costs of rigid pavement take into account the changes to particular elements, materials and structures.

Blue Eyes Intelligence Engineering \& Sciences Publication

(C) Copyright: All rights reserved.

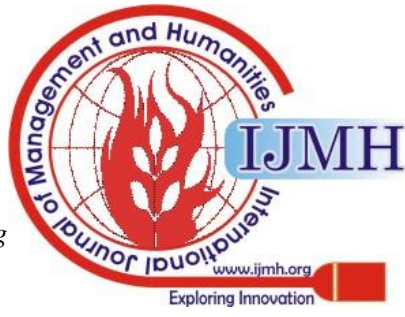


These costs include staff salaries, supervision and installation charges, maintenance contractor's preliminaries, administrative cost, consultant fees and specialist work costs.

\section{E. Quality Data Input Requirements of LCC for Rigid Pavement Maintenance and Rehabilitation}

Cost data inputs are the most crucial components in carrying out LCC analysis[21]. The cost data inputs should be recognized and quantified by the estimators in the very early stage of the project[7]. The maintenance costs of rigid pavement are by far the most challenging to be estimated as there is a need for the establishment of planned and required maintenance works and timings to be done [14]. Besides that, the solid guideline that can assist the transportation agencies in managing the data for maintenance and rehabilitation works have not yet existed as the nature of rigid pavement is complex and complicated [22]. Based on the review of the literature, it was observed that there is no maintenance cost data of rigid pavement available and published in the Malaysian construction industry in order to help the cost estimators to estimate the total maintenance cost of rigid pavement. In a study that set out to determine the quality of cost data inputs to produce a reliable LCC output, the key quality of cost data input requirements are data availability, accessibility, currency and reliability [7]. The degrees and descriptions of data availability, accessibility, currency and reliability in the quality of cost data input requirements required for LCC analysis are shown in table 4 below. Data availability refers to the certainty of the cost data to be used in LCC analysis and data accessibility refers to the ease of access in obtaining the cost data to be used in the LCC analysis. Besides that, the currency of cost data presents the recent and updated cost data inputs; and the reliability of cost data refers to the accuracy and consistency of the cost data to be used as inputs for LCC analysis. These key quality requirements are also appropriate to be applied in identifying and checking current and reliable cost data for producing a complete and reliable LCC analysis of rigid pavements maintenance and rehabilitation. The literature study has identified that there is no quality data requirement, which has been established in the Malaysian construction industry that can help the LCC estimators to identify the quality degree of cost data as inputs for producing a comprehensive and reliable LCC analysis of rigid pavement maintenance and rehabilitation [7].

\section{METHODOLOGY}

The study conducted a systematic literature review to provide an overview of the wide range of elements and models of LCC analysis in pavement rehabilitation and maintenance and, and to explore the state of cost data inputs that can be used construction industry in Malaysia for life cycle cost analysis of rigid pavement rehabilitation and maintenance. The life-cycle value literature was quite dispersed and they suggested the origin of online databases as it is more desirable to provide LCC literature than individual journals. These results tend to be consistent with other LCC researchers who have previously researched LCC[23]. The authors used keywords to search and classify relevant journal articles, conference papers and documents from 2000 to 2019 from multiple online databases covering general, scientific, engineering and economics disciplines. These include IEEE Xplore, Emerald Research, Taylor \& Francis Online, ScienceDirect, and Google Scholar. The following are the keywords that were used in the literature search: i.e. I "life cycle cost" AND cost data, (ii) "life cycle cost" AND pavement maintenance, and (iii) "life cycle cost" AND rigid pavement maintenance. The word "life cycle value" has been sought from all text fields as the paper's emphasis lies within the scope of the cost of the life cycle. The other terms, i.e. cost information, pavement, pavement maintenance and rigid pavement maintenance, were used but restricted to the abstract, title or keywords section of the papers as the articles were not considered as important when the terms were not listed in these parts. The online literature search was performed in Google Scholar, however, but was restricted to the article title only because keywords cannot be used to find the required information on the article page. The literature search results are summarized in Table 2. Some of these articles have been screened and excluded from the literature review due to limited access to the full text and failure to meet the study's requirements and scope. Referring to the results recorded in Table 2, it can be seen that there is currently very limited online publication focusing on the subject, i.e. the cost of the life cycle and the rigid maintenance of pavement. This means that more studies to increase the publication in relation to the life cycle cost and rigid pavement maintenance are necessarily needed to be carried out to provide enhancement of knowledge on LCC practice.

Table 2: Search keywords and result

\begin{tabular}{|c|c|c|c|c|}
\hline Database & $\begin{array}{c}\text { "life } \\
\text { cycle } \\
\text { cost" } \\
\text { AND } \\
\text { cost } \\
\text { data }\end{array}$ & $\begin{array}{c}\text { "life } \\
\text { cycle } \\
\text { cost" } \\
\text { AND } \\
\text { pave } \\
\text { ment }\end{array}$ & $\begin{array}{c}\text { "life cycle } \\
\text { cost" AND } \\
\text { pavement } \\
\text { maintenance }\end{array}$ & $\begin{array}{c}\text { "life cycle } \\
\text { cost" } \\
\text { AND } \\
\text { rigid } \\
\text { pavement } \\
\text { maintenance }\end{array}$ \\
\hline IEEE Xplore & 650 & 20 & 20 & 2 \\
\hline $\begin{array}{c}\text { Emerald } \\
\text { Insight }\end{array}$ & 900 & 100 & 30 & 0 \\
\hline ScienceDirect & 7000 & 700 & 200 & 10 \\
\hline $\begin{array}{c}\text { Taylor \& } \\
\text { Francis } \\
\text { Online }\end{array}$ & 50 & 300 & 50 & 0 \\
\hline $\begin{array}{c}\text { Google } \\
\text { Scholar }\end{array}$ & 70 & 200 & 50 & 0 \\
\hline
\end{tabular}

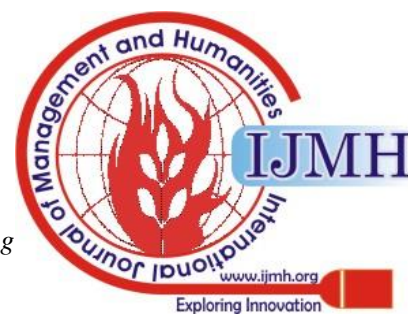


Table 3: Type of cost data of LCC for rigid pavement maintenance and rehabilitation[1]

\begin{tabular}{|l|l|}
\hline Cost data type & \multicolumn{1}{c|}{ Description } \\
\hline Supervision and installation & All cost related to the process of supervising and monitoring \\
\hline charges & during execution of the works \\
\hline $\begin{array}{l}\text { Maintenance } \\
\text { contractor's } \\
\text { preliminaries }\end{array}$ & $\begin{array}{l}\text { The scope of the element of preliminaries such as temporary works, protection, } \\
\text { watching, hoarding, testing, site supervision and overheads }\end{array}$ \\
\hline $\begin{array}{l}\text { Administrative } \\
\text { costs }\end{array}$ & $\begin{array}{l}\text { Administration cost includes contract management, legal expenses, } \\
\text { professional expenses and executive salaries }\end{array}$ \\
\hline $\begin{array}{l}\text { Specialist works } \\
\text { costs }\end{array}$ & $\begin{array}{l}\text { Fees allocated to the contractor that has been appointed to carry out specialist } \\
\text { works where it involves specialist construction knowledge and skills. }\end{array}$ \\
\hline
\end{tabular}

Table 4: The quality degrees of cost data inputs of LCC analysis[1]

\begin{tabular}{|c|c|c|}
\hline $\begin{array}{l}\text { The key quality of data } \\
\text { input requirement }\end{array}$ & $\begin{array}{l}\text { The degree of data } \\
\text { inputs }\end{array}$ & Description \\
\hline \multirow[t]{3}{*}{ Availability } & Highly available & Data are freely published online and unrestricted for public use \\
\hline & Available & $\begin{array}{l}\text { Data are available for LCC analysis but need to subscribe from the } \\
\text { subscriber-base information services provided }\end{array}$ \\
\hline & Limited & Internal data that confined by firms or organizations in the library \\
\hline \multirow[t]{3}{*}{ Accessibility } & Highly accessible & Data are freely published online and unrestricted for public use \\
\hline & Accessible & $\begin{array}{l}\text { Data that need to subscribe from the subscriber-base information } \\
\text { services provided }\end{array}$ \\
\hline & Limited & Data that have limited public access \\
\hline \multirow[t]{3}{*}{ Currency } & Very current & $\begin{array}{l}\text { Data are very often updated either on the weekly, monthly, quarterly } \\
\text { or yearly basis }\end{array}$ \\
\hline & Current & $\begin{array}{l}\text { Data are updated once in a couple years or more but less than } 5 \text { years } \\
\text { period }\end{array}$ \\
\hline & Less current & Data are updated once in a period of more than 5 years \\
\hline \multirow[t]{3}{*}{ Reliability } & Very reliable & $\begin{array}{l}\text { The most structured data that are formed in detail, completeness and } \\
\text { adequate, and compatible to be used as inputs into the process of } \\
\text { generating reliable LCC analysis }\end{array}$ \\
\hline & Reliable & $\begin{array}{l}\text { Data are consistent and comparable to the actual value which arrived } \\
\text { from similar and repetitive methods under the same research } \\
\text { condition }\end{array}$ \\
\hline & Less reliable & $\begin{array}{l}\text { Data are incomplete, inadequate and incompatible which produce } \\
\text { outputs not consistent over time }\end{array}$ \\
\hline
\end{tabular}

Table 5: The state of data availability, accessibility, currency and reliability for LCC analysis of rigid pavement maintenance and rehabilitation[1]

\begin{tabular}{|c|c|c|c|c|}
\hline Cost data types & \multicolumn{4}{|c|}{ State of published cost data } \\
\hline & Availability & Accessibility & Currency & Reliability \\
\hline $\begin{array}{l}\text { Supervision and } \\
\text { installation charges }\end{array}$ & \multirow{2}{*}{$\begin{array}{l}\text { The data are available and can be } \\
\text { obtained from the respective local } \\
\text { state agencies i.e. Kuala Lumpur } \\
\text { City Hall (DBKL), PWD, highway } \\
\text { operator and concessionaires, } \\
\text { contractors, professional bodies etc. }\end{array}$} & \multirow{2}{*}{$\begin{array}{l}\text { All these data } \\
\text { have limited } \\
\text { accessibility for } \\
\text { public use. }\end{array}$} & & $\begin{array}{l}\text { All these data are } \\
\text { less reliable. }\end{array}$ \\
\hline Administrative cost & & & & \\
\hline $\begin{array}{l}\text { Specialist works } \\
\text { cost }\end{array}$ & & & $\begin{array}{l}\text { Public Works } \\
\text { Department has } \\
\text { published cost data } \\
\text { for rehabilitation, } \\
\text { but the cost data is } \\
\text { not frequently } \\
\text { updated. }\end{array}$ & \\
\hline
\end{tabular}




\begin{tabular}{|c|c|c|c|}
\hline $\begin{array}{l}\text { Traffic } \\
\text { management and } \\
\text { control cost }\end{array}$ & $\begin{array}{l}\text { The data cost for traffic } \\
\text { management and control also is } \\
\text { freely published online by the PWD } \\
\text { on the corporate website and the } \\
\text { data is highly available for public } \\
\text { use. }\end{array}$ & $\begin{array}{l}\text { The data cost for } \\
\text { traffic management } \\
\text { and control also is } \\
\text { freely published } \\
\text { online by the PWD } \\
\text { in the corporate } \\
\text { website and highly } \\
\text { accessible for public } \\
\text { use. }\end{array}$ & $\begin{array}{l}\text { The cost data for } \\
\text { traffic } \\
\text { management and } \\
\text { control is very } \\
\text { reliable. }\end{array}$ \\
\hline
\end{tabular}

\section{RESULT AND DISCUSSION}

For LCC analysis of rigid pavement maintenance and rehabilitation, a considerable amount of literature has been reviewed to study the current state of cost data inputs in terms of their availability, accessibility, currency and reliability in Malaysia. The results of the review presented in Figure 4 showed that the data in Malaysia are not sufficiently ready and detailed to be used as inputs for LCC analysis of rigid pavement maintenance and rehabilitation due to the lack of reliability required to meet all the key quality data input criteria of LCC analysis (i.e. availability, accessibility, currency and rehabilitation). For example, table 3 shows that although data on monitoring and installation charges are available, data is limited to internal use within the organization and data is not frequently updated. In order to produce a reliable LCC analysis of rigid pavement maintenance and rehabilitation, the data are considered not to be reliable to be used as inputs. This results in the inadequacies of cost data inputs for rigid pavement maintenance and rehabilitation that has been pointed out to be one of the main obstacles to implement LCC analysis in the Malaysian construction industry [7].

\section{CONCLUSION}

During the in-use phases of rigid pavement in Malaysia, this paper analyzed the condition of LCC maintenance study. The literature review found that the introduction of rigid pavement maintenance and rehabilitation LCC research in the Malaysian construction industry is still at an early stage. This is due to the difficulty of obtaining total, accurate and current cost information as inputs into the method of producing a detailed and reliable maintenance LCC analysis during the rigid pavement phases of in-use. The inadequacies of quality cost information inputs for rigid pavement maintenance and rehabilitation indicate that in the Malaysian construction industry, the LCC procedure is not ready to be applied. In addition, the lack of cost data related to maintenance and reconstruction is due to the fact that most pavement authorities do not have appropriate methods for systematic data collection or follow-up procedures for preparing, designing, building and maintaining the rigid pavement. Research is ongoing and further research is encouraged as a second part of the study to identify appropriate strategies to mitigate the aforementioned limitations of rigid pavement maintenance LCC analysis and to improve the quality of LCC data inputs for a comprehensive and reliable LCC estimate of rigid pavement maintenance approaches in the construction industry in Malaysia.

\section{ACKNOWLEDGEMENT}

The author would like to thank the Ministry of Education (MOE) Malaysia through Research University Grant (RUG) No 1501 UTM funding project title Development of Biocement Using Ex Situ Mixing Technique for Construction Materials, for financial assistances while conducting this research project.

\section{REFERENCES}

1. S. Z. A. Jasmi, K. A. R. , Mohd Fairullazi Ayob, and A. M. Faizul Rahim, "A Review on the State of Cost Data Inputs of Life Cycle Cost (LCC) for Rigid Pavement Maintenance and Rehabilitation in Malaysia," J. Deisgn Built Environ., no. 1, 2018.

2. M. A. Hassanain, A. M. Al-Hammad, and F. Fatayer, "Assessment of architectural defects attributed to lack of maintenance feedback to the design team," Archit. Sci. Rev., vol. 57, no. 2, pp. 132-138, 2014.

3. M. mail Online, "PLUS spent RM1b in 2016 to maintain highways , says," 2018.

4. S. Z. Ayob, M. F., Abdul Rashid, K., Bidi, N.K. and Ahmad Jasmi, "Identification of cost data inputs in Life Cycle Cost (LCC) of alternative road pavement types (profile of final report of RAGS project for Ministry of Education Malaysia)Research Report. (Unpublished).," 2017.

5. Wan Imran Wan Omar., "Evaluating lifecycle cost (LCC) and performance between cold in-place recycling (CIPR) and reconstruction method. Unpublished master dissertation, Kulliyah of Architecture and Environmental Design.International Islamic University, Malaysia.," 2015

6. A. S. Awang, N.A, Shirley Jin Lin Chua and Ali., "Building Condition Assessment Focusing on Persons with Disabilities' Facilities at Hospital Buildings.," J. Des. Built Environ., no. Special, 2017.

7. M. F. Ayob, Development of life cycle cost strategy and protocol on data input in Malaysia. Unpublished doctoral dissertation, Kulliyyah of Architecture and Environmental Design. International Islamic University, Malaysia.," 2014

8. E. P. Unit, "Eleventh Malaysia Plan 2016-2020.," 2015

9. A. Nikolaides, "Highway Engineering: Pavements, Materials, and Control of Quality.," Boca Rat. CRC Press Taylor Fr. Group., 2015.

10. R. L. Singh, D., \& Tiong, "Development of e cycle costing framework for highway bridges in Myanmar.," Int. J. Proj. Manag., vol. 23, no. 1, pp. 37-44, 2005.

11. T. Mallick, R. B., \& El-Korchi, "Pavement engineering: principles and practice.," CRC Press.

12. \& Reina, A., Kocsis, Á., Merlo, A., Németh, I. and F. Aggogeri, "Maintenance decision support for manufacturing systems based on the minimization of the life cycle cost.," Procedia, vol. 57, pp. 674-679, 2016.

13. G. M. Ramachandran, "Life-Cycle Costing Analysis : Mandatory for all infrastructure projects.," Retrieved from https//www.linkedin.com/pulse/life-cyclecosting-analysis-mandatory-all-projects- ramachandran, 2017.

14. A. Tinni, "Cautions with life cycle cost analysis for optimal pavement selection.," Concr. Assoc. Est. Mar., 2013.

15. BSI, "Standardized method of life cycle costing for construction procurement: A supplement to BS ISO 15686-5 Buildings and constructed assets-Service Life Planning. Part 5: Life Cycle Costing.," London Br. Stand. Institutions., 2008.

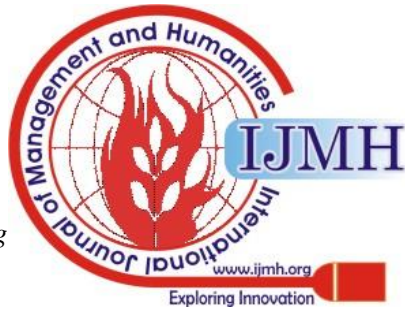


16. K. Ayob, M. F. and Abdul Rashid, "Strategies to enhance quality data input requirements of life cycle cost (LCC).," J. Archit. Plan. Constr. Manag., vol. 3, no. 2, pp. 44-67, 2013.

17. R. Islam, S. F. Mohamed, S. Bjørberg, M. S. Misnan, and Z. M. Yusof, "Towards a Framework to Integrate Facilities Management Cost Effective Parameters in Design Process," Int. J. Eng. Technol., vol. 9, no. 6, pp. 4515-4526, 2017.

18. \& G. Rangaraju, P. R., Amirkhanian, S. N. and Z., "Life cycle cost analysis for pavement type selection (No. FHWA-SC-08- 01).," South Carolina Dep. Transp., 2008.

19. I. Mahamid, "Early cost estimating for road construction projects using multiple regression techniques.," Australas. J. Constr. Econ. Build., vol. 11, no. 4, 2011.

20. K. D. Herbold, "Using Monte Carlo simulation for pavement cost analysis.," Public Roads, vol. 64, no. 3, pp. 2-6, 2000.

21. D. Langdon, "Development of a promotional campaign for Life Cycle Costing in construction.," United Kingdom: Davis Langdon., 2010.

22. V. Suanmali, S., \& Ammarapala, "Maintenance budget planning: A case study for rigid pavement maintenance system in Thailand. In Service Systems and Service Management (ICSSSM)," IEEE., 2010.

23. T. Korpi, E., \& Ala-Risku, "Life cycle costing: a review of published case studies.," Manag. Audit. Journal, vol. 23, no. 3, pp. 240-261, 2008.

\section{AUTHORS PROFILE}

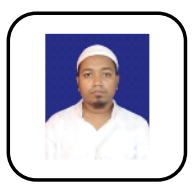

MONIRUL ISLAM is currently a graduate research assistant at the Department of Quantity Surveying, Universiti Teknologi Malaysia, Johor Baharu, Johor. The author obtained his first degree in civil engineering in 2011 at the Bangladesh University of Engineering and Technology (BUET), Dhaka, Bangladesh. He has been working as an assistant engineer at Local Government Engineering Department (LGED). The research area is on Development of Operation and Maintenance Cost Model for Highway Projects. He is register Civil Engineer certified by the Institution of Engineers, Bangladesh. Now he attends a MPhil program in Quantity Surveying at the Universiti Teknologi Malaysia. He has more than 8 years of working experiences in field works in the consultancy firm, government and semi-government projects.

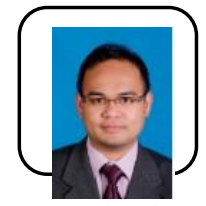

ASSOCIATE PROFESSOR Sr DR. SARAJUL FIKRI MOHAMED is an academic staff at the Department of Quantity Surveying, Universiti Teknologi Malaysia, Johor Baharu, Johor where he specializes in Construction Management, Project Estimating and Construction Innovation. He obtained B.Sc. in Quantity Surveying from Universiti Teknologi Malaysia (UTM). In the year 2002, he completed his Master of Science in Construction Innovation and $\mathrm{PhD}$ in Construction Management in 2006 from Loughborough University, United Kingdom. His research areas include construction procurement, construction innovation and commercial management in construction. Prior to this, he worked as property and construction consultant at MDA Consulting UK. The examples of projects he was involved in are Stratford Western Relief Road (Warwickshire County Council), William Baker Building (University of De Montfort), Airfield Business Park Market Harborough (William Davis), and Sport Complex Building (Leicestershire County Council). He has more than 17 years working experiences in related field.

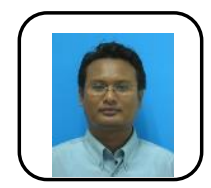

SENIOR LECTURAR Sr DR. SYAMSUL HENDRA BIN MAHMUD is an academic staff at the Department of Quantity Surveying, Universiti Teknologi Malaysia, Johor Baharu, Johor where he specializes in Construction Management, Project Estimating and Construction Innovation. He obtained B.Sc. in Quantity Surveying from Universiti Teknologi Malaysia (UTM). In the year 2002, he completed his Master of Science in Construction Innovation and $\mathrm{PhD}$ in Construction Management in 2006 from Loughborough University, United Kingdom. His research areas include construction procurement, construction innovation and commercial management in construction. Prior to this, he worked as property and construction consultant at MDA Consulting UK. The examples of projects he was involved in are Stratford Western Relief Road (Warwickshire County Council), William Baker Building (University of De Montfort), Airfield Business Park Market Harborough (William Davis), and Sport Complex Building (Leicestershire County Council). He has more than 17 years working experiences in related field.

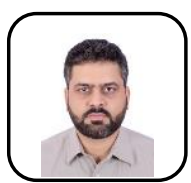

My name is Khalid Alghamdi I am from Makkah, Saudi Arabia. I studied Design and earned a bachelor's degree in Graphic Design from Umm Al-Qura University in 2007. Since then, I have been working as a teacher assistant at the Graphic Design department at the same university. While working as a teacher assistant, I participated in several researches, studies, and design projects at Excellence in Haj and Umra Research (CEHOR) and other centers in Saudi Arabia. In 2010, based on excellence in work and effort he received a full scholarship at the University of New South Wales in Sydney. Then in 2012, he earned a Master's degree in Design from the University of New South Wales college of Fine Arts in 2012, also I work as a contemporary artist and I have a lot of art projects acquired from the Saudi Contemporary Museum in Riyadh and Ather gallery and Hafez Gallery in Jeddah. Now I attend a Ph.D. program in urban and regional planning at University Technology Malaysia.

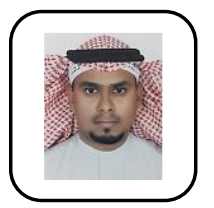

Abdullah Karban is a Lecturer of Urban Regional Planning in the College of Engineering and Islamic Architecture at Umm Al-Qura University. He earned a bachelor's degree in Architecture from Umm Al-Qura University and earned a master's degree in urban and regional planning from the University of Texas at San Antonio. He is a Ph.D. candidate in urban and regional planning at University Technology Malaysia. Prior to joining University Technology Malaysia, Mr. Karban has been participating in several researches, studies and design projects at Excellence in Haj and Umra Research (CEHOR) and other centers in Saudi Arabia. He worked as a Graduate Research Assistant at the Center for Urban and Regional Planning Research, at The University of Texas at San Antonio. he also worked as co-coordinator at prince Khaled Al-Faisal Chair for developing informal areas in Makkah region. Recently, he worked as a consultant planner in crowding management project at $\mathrm{Al}$ Mashaaer Al Mugaddassah Metro line in the Holy city of Makkah. His research interests include sustainable and urban development, neighborhoods developments, hospitality, historic preservation, religious tourism, and urban history.

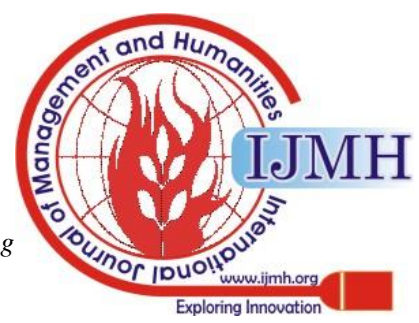

